\title{
ZORA NEALE HURSTON SAYS, "SONGS ARE BUILT ON THE POWER TO CHARM BENEATH THE BED-CLOTHES."
}

Little

intimate names

indulged to heap fire on fire.

She called him "mouth to mouth and Jook to Jook"

and he whispered on her neck, "full of beauty and this lack of

symmetry." Compelling insinuation.

She cannot quite talk.

The pillow is not in the center of the bed,

muffle-jawed. Supplication

forgotten,

a taut lip, a full lip

in the frenzy of creation.

Their gift song came back

into their memories, in pieces. 